\title{
MANIPULATIVE CAPACITY IN THE APPLICATION OF THE COMPARISON MECHANISM
}

\author{
BENIK YERIBEKYAN \\ Armenian State Pedagogical University after Kh. Abovyan, Applicant, \\ Lecturer at Vanadzor State University \\ byeribekyan@bk.ru \\ https://doi.org/10.52853/25792903-2021.2-bymc
}

\section{A bstract}

The article presents some theoretical justifications and some features of the origin of the comparison mechanism.

Some areas of the practical application of the comparison mechanism were also presented, and the main manipulative intentions were analyzed. The theoretical part considers and analyzes the problems and features of the development of a comparison mechanism In particular, the Adler theory is analyzed. The author substantiates the fact that the basis of the comparison mechanism originates in early childhood. In this process, a particular role and significance is the fact of comparison with siblings. The theory of object relations is also considered a theoretical basis, especially regarding the psychological structure of the narcissistic personality. In this context, the psychoanalytic approach is regarded as a profound basis for forming a psychological comparison mechanism and later becomes a stable behavioural pattern. The correlation between the emergence of the psychological comparison mechanism and the influence of the individual's environment is also theoretically justified. The formed behavioural pattern becomes the basis for subsequent manipulations in the field of social psychology. In particular, the concept of a reference group is when an individual compares himself with members of his group and groups of opponents. In this case, using this mechanism, you can build the foundations of national identity and, as an additional tactic using the mechanism of depreciation. In marketing, a manipulative comparison mechanism is used to influence the self-image In this case, a particular consumer is identified with this image by comparing himself to the advertising image In the political and marketing spheres, manipulative use of the comparison mechanism can be found very often. The phenomenon of manipulation in this context concerns the concept of intention. The main manipulative intention is the desire to devalue. In politics, devaluation is often used, and in marketing, dominance is used. In the context of the latter, appropriate language is used.

The manipulative use of the comparison mechanism is considered in the example of the discursive practices of representatives of individual political elites. In the political sphere, in using the comparison mechanism the intention of devaluation, narcissistic comparison is mainly used. This process can particularly be seen when comparing the speech of the President of Georgia with the statement of the President of Ukraine. Using the example of President Zelensky's statement, one can see the use of a symbolic image, which 
provides even greater power of mani pulative influence on one's audience. In marketing and advertising, the comparison mechanism is combined with the demonstration of the advantages of your own product compared to others.

Keywords and phrases: comparison mechanism manipulative intentions, discursive markers, impact.

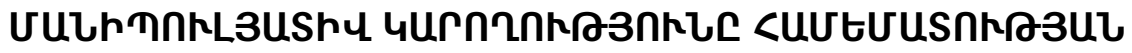

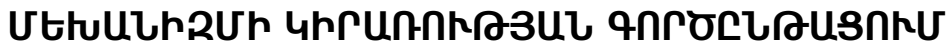

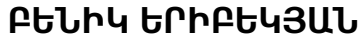

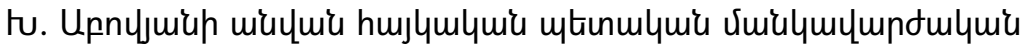

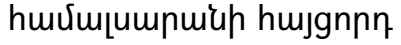

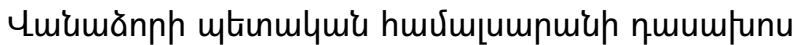 \\ byeribekyan@bk.ru
}

\section{Cunumnnunuqhp}

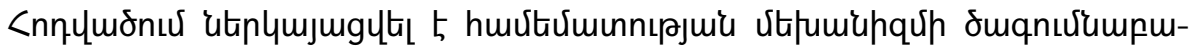

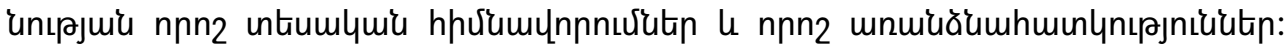

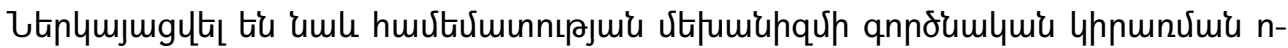

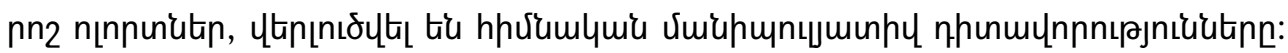

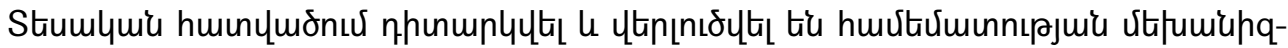

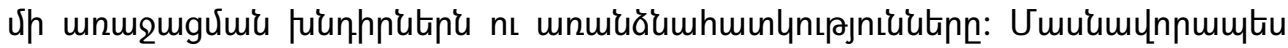

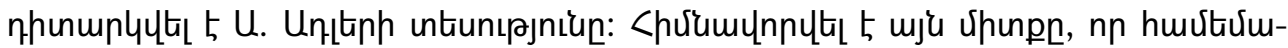

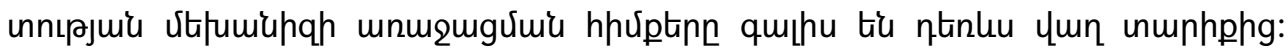

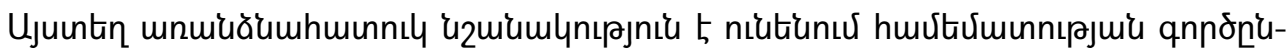

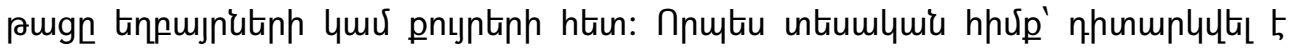

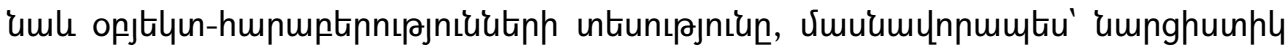

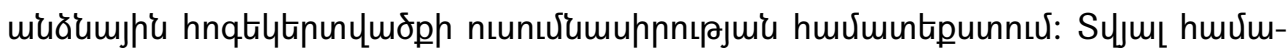

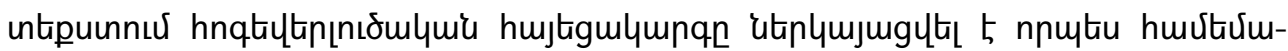

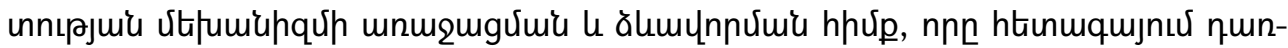

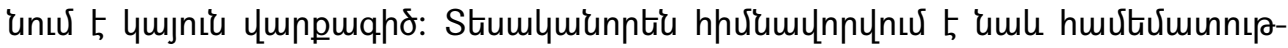

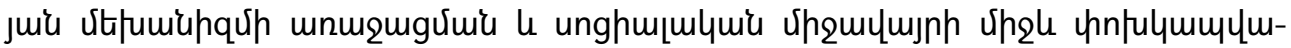

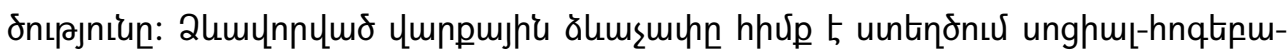

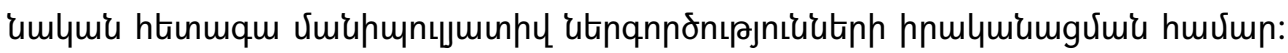




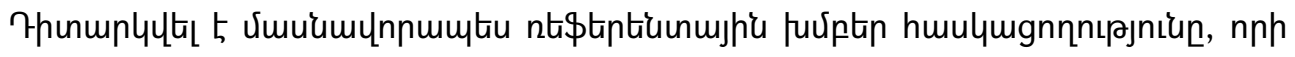

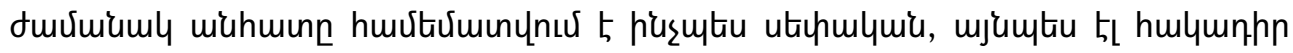

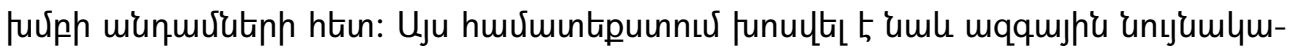

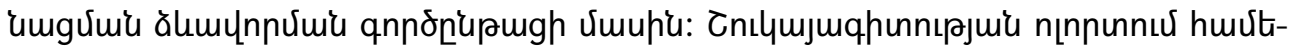

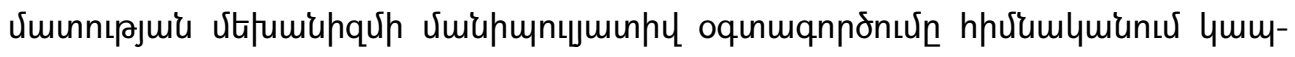

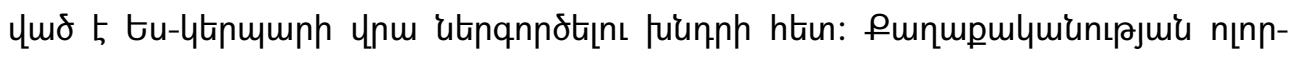

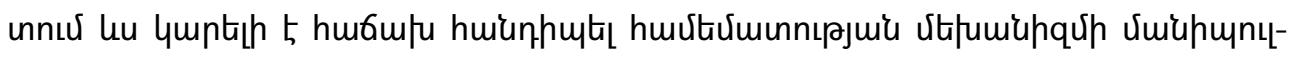

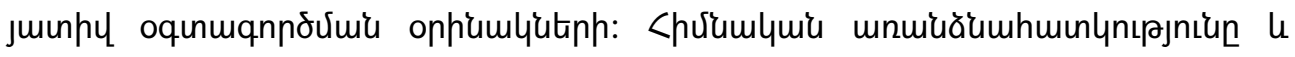

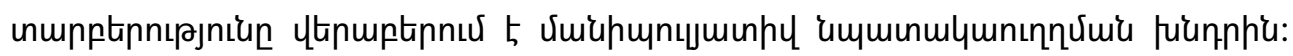

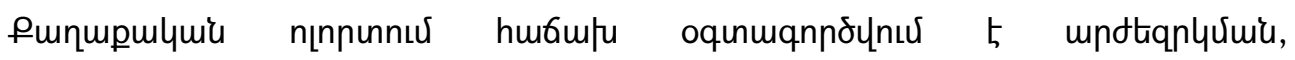

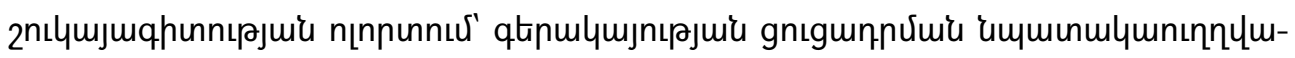

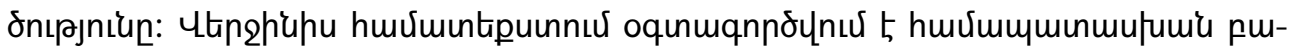
nuर्uptnp:

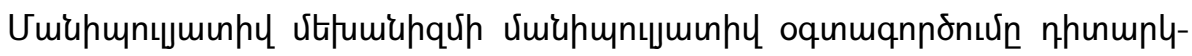

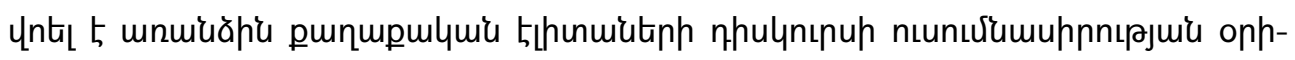

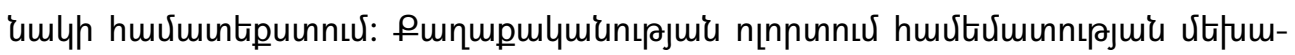

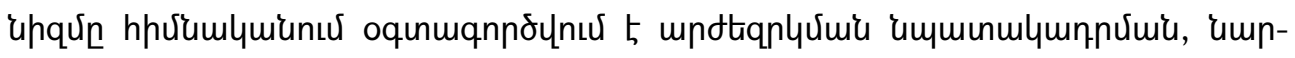

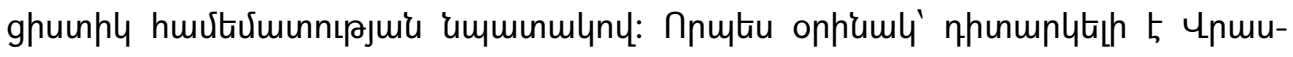

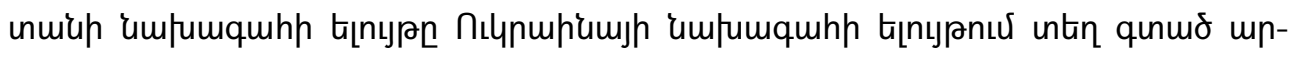

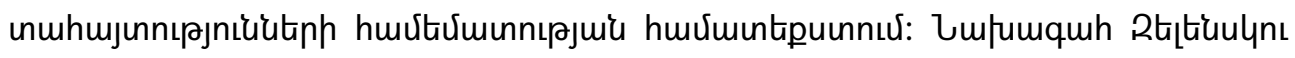

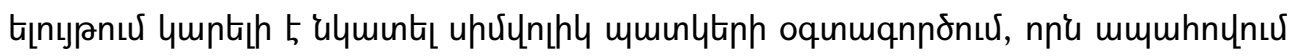

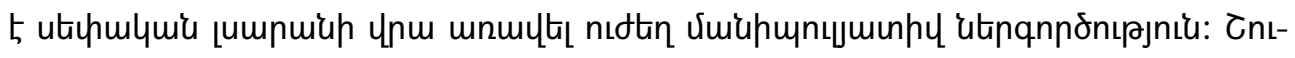

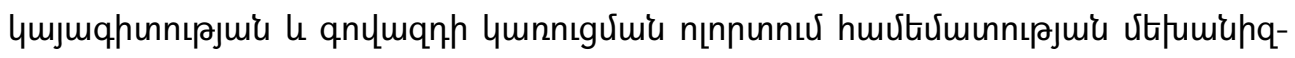

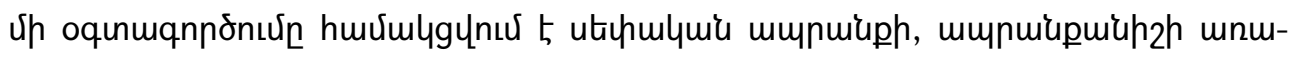

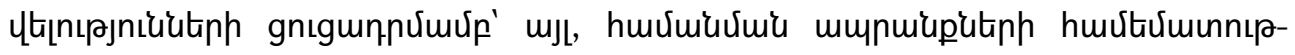
juúp:

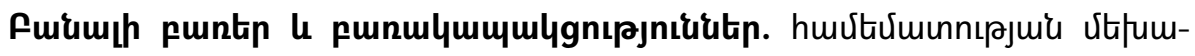

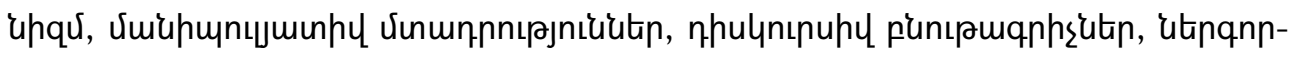

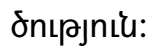




\title{
МАНИПУЛЯЦИОННАЯ СПОСОБНОСТЬ ПРИ ПРИМЕНЕНИИ МЕХАНИЗМА СРАВНЕНИЯ
}

\author{
БЕНИК ЕРИБЕКЯН \\ Соискатель Армянского государственного педагогического университета им. Х. \\ Абовяна, \\ преподаватель Ванадзорского государственного университета \\ byeribekyan@bk.ru
}

\begin{abstract}
Аннотация
В статье рассматриваются некоторые особенности использования механизма сравнения, приводятся теоретические обоснования его возникновения. Рассматриваются также прикладные области применения механизма сравнения, анализируются основные манипулятивные интенции. В теоретической части рассматриваются вопросы возникновения и особенности механизма сравнения. В частности, анализируется адлеровская теория. Обосновывается тот факт, что основы механизма сравнения берут свое начало в раннем детстве. В данном процессе особую роль и значение имеет факт сравнения с сиблингами. В качестве теоретических основ рассматривается также теория объектных отношений, в частности, в контексте изучения психологической структуры нарциссической личности. В данном контексте психоаналитический подход рассматривается в качестве глубинной основы формирования психологического механизма сравнения, который в дальнейшем становится неким устойчивым поведенческим паттерном. Также теоретически обосновывается факт корреляции между возникновением психологического механизма сравнения и влиянием окружения индивида. Данный поведенческий паттерн становится основой для последующих манипуляций в сфере социальной психологии. Рассматривается, в частности, понятие референтной группы, когда индивид сравнивает себя как с членами собственной группы, так и с группами оппонентов. В данном случае, используя этот механизм, можно выстраивать основы национальной идентичности, а в качестве дополнительной тактики использовать также механизм обесценивания. В сфере маркетинга манипулятивный механизм сравнения используется с целью влияния на Я-образ. В данном случае конкретный потребитель, сравнивая себя с рекламным образом, идентифицируется с последним. В политической сфере также часто встречается манипулятивное использование механизма сравнения. Манипулятивность в данном контексте касается понятия интенции. В качестве основной манипулятивной интенции выступает стремление к обесцениванию. В политической сфере данный процесс касается интенции обесценивания политического оппонента. В сфере маркетинга основной манипулятивной интенцией является интенция доминирования и превосходства. В данном процессе особое значение приобретает также использование определенных словесных маркеров и формулировок.
\end{abstract}


Манипулятивное использование механизма сравнения рассматривается на примере дискурсивных практик представителей отдельных политических элит. В политической сфере в процессе использования механизма сравнения в основном используется интенция обесценивания, нарциссического сравнения. В частности, данный процесс можно усмотреть на примере сравнения выступления президента Грузии с высказываниями президента Украины. На примере высказывания президента Зеленского можно увидеть использование символического образа, что обеспечивает еще большую силу манипулятивного воздействия на собственную аудиторию. В сфере маркетинга и построения рекламы механизм сравнения совмещается с демонстрацией преимуществ собственного продукта по сравнению с другими аналогичными продуктами.

Ключевые слова и словосочетания: механизм сравнения, манипулятивные интенции, дискурсивные маркеры, воздействие.

\section{Introduction}

The modern world is in a state of gl obal social changes. These changes concern both the geopolitical situation in the world, and the psychology of the individual, the mentality of the nation. All this also requires the development of certain adaptive mechanisms to the changing environment.

In this regard, we can see different rates, paces and features of these adaptive processes. In some societies, the fact and inevitability of change cause uncertainty and anxiety; there are no special difficulties in this matter in other societies. This psychol ogical stability can be associated with the economic or military development of a given state and society.

Political and economic stability and resilience can avoid severe societal shocks that could arise in changing world order. And after any such shocks, society must adapt at the level of its attitudes and mentality.

Information also plays a special role in this process. With its help, data is often exchanged. As a result, individuals and societies get acquainted with the ongoing changes in the world and new trends that are becoming relevant at a given time.

However, very often, the information is used for entirely different purposes. It becomes a tool for influencing, manipulating, and changing the attitudes and moods of the audience. In this regard, we can no longer talk about the transfer of the information but about its modification, interpretation and fraudulent use.

Nevertheless, the strong influence and role of manipulative information processes in the modem world remain indisputable.

In addition, in the modern world, you can al so see some struggle for superiority. This desire for excellence can be seen both in the economic, military, and the field of mentality, development, and historical origin of a particular nation. 
To achieve this superiority, very often, information and facts can be changed, or certain manipulative techniques and strategies can be used in them However, it all depends on the specific goal set.

In this regard, the narcissistic fixation of the modem world order is an indisputable fact for us. In this regard, the comparison process becomes significant. Comparing your own and other people's society, nation, history, and development with your opponents, an attempt is made to establish and strengthen your own national identity. Thus, the comparison process is the primary manipulative strategy here.

The article examines the features of the manipulative use of the comparison process as a tool for devaluing the opponent and strengthening one's own national identity and consolidation.

The object of the study is the manipulative use of the comparison process.

The subject of the study is the identification of discursive markers of the use of the comparison process.

The method used is the method of discursive analysis, in particular, the discourse analysis of media texts.

\section{Theoretical aspects of the origin of the comparison mechanism}

In contrast to Freud's theory, A. Adler based his theory on the concept of innate, basic inferiority. In this regard, he singled out the concepts of inferiority and the desire and quest for superiority as a compensatory mechanism for overcoming this inferiority. Feelings of inferiority can persist into adulthood. In this regard, Adler saw the primary goal of human activity as the pursuit of excellence. One of the essential motivators of human development A. Adler considered the purpose of a goal [2].

As for the question of comparison, it is necessary to mention some aspects of individual psychology regarding the order of birth and the child's relationship with siblings.

In particular, the eldest child is seen as the leader, and the second child tends to overtake the leader. The older child is often afraid and avoids competition, unlike the second sibling [2].

As a basic effect in sibling relationships, jeal ousy is considered. In this regard, it is mentioned that the nature of jealousy intensity also depends on the characteristics and style of parental education [11].

It can be concluded that the comparison mechanism is considered one of the primary mechanisms for regulating human behaviour. Moreover, based on early childhood impressions, the comparison mechanism does not lose its relevance in the adult life of the human. 
In the psychoanal ytic literature, the comparison process can be seen in particular in the dynamics of narcissistic personality disorder, where one of the main protective mechanisms is the deval uation of the opponent's image [5], [6].

In social psychology, the topic of social comparison has different manifestations. We can give an example of the theory of conformity when a person compares and coordinates his attitudes with the attitudes and views of the majority [4].

The principle of social proof can also serve as an example of social comparison when an individual is guided by the opinions of a particular group of people in matters of his own choice [9].

Crowd psychology is also an example of social proof when an individual looks at the impunity of other crowd members and adopts this experience [7], [8].

We can also give an example of the concept of a reference group, which coordinates and controls the behaviour of a person belonging to this group. The reference group also eval uates the behaviour and actions of the individual. In the end, it becomes some basis of inner self-awareness and part of the self-concept. In the future, the person begins to navigate and compare himself with his behaviour [11].

The manipulative use of comparison can also be seen in the construction of national identity when the opponent's example constructs its national image. Very often, psychological depreciation is al so used in this process [1].

Comparison as a manipulative strategy is often used in the construction of advertising and the marketing business. In this case, we can also talk about some adjustments to the audience's values; for instance, family relations, the image of a successful woman or man, a successful businessman. All this encourages the audience to compare their self-concept with the images in advertising [3].

Thus, we can see a lot of areas of human and social activity where the comparison mechanism acts as a means of manipulative influence. We also showed that the comparison process is essential and starts from early childhood. This fact seems important to us since it is the core around which we can observe the manipulative action of the comparison mechanismin the future.

We can also add that the manipulative basis of the comparison mechanism is laid by parental upbringing and parental attitudes when a particular child is compared with other children.

In the next section of this article, we will try to consider some areas of application of the comparison mechanism, analyze the manipulative intentions and tactics of the comparison mechanism in advertising, the political sphere, and the process of building national identity. 


\section{R esearch of some manipulative intentions of the comparison mechanism}

Significantly often, the manipulative mechanism of comparison can be seen in the sphere of politics and political struggle. The comparison here is mainly used with specific intentions. It is the intention of depreciation. However, in some cases, we can see the purpose of idealization.

An example of the devaluing intention of comparison is the statement of the Turkish president to the German and Dutch authorities, where the Nazis compare them It is also demonstrated that this tactic was also used by British Prime Minister Boris J ohnson before Brexit when he compared the European Union to the Nazis [13].

In both cases, we can talk about using the comparison mechanism with the manipulative intention of devaluation. Such processes take place mainly in the context of discursive struggle. They are primarily ai med at changing the views and attitudes of the audience of their own country and justifying the correctness of their policies.

The comparison process can also be seen in the political discussions of the Georgian political elite when President Sal ome Zurabishvili's speech was compared to the speech of President of Ukraine Vladimir Zelensky. The main accusation concerned vague and abstract statements of the President of Georgia, in contrast to the harsh and concrete address of the President of Ukraine [14].

In this example, the comparison mechanismis not used for depreciation. Instead, the main intention here is to set an example of the speech of another speaker and al so to direct and change the primary vector of the speech direction.

We can give another example of manipulative comparison, where the main intention is to devalue the opponent. President of Ukraine V. Zelensky refused to purchase a Russian coronavirus vaccine. The low effectiveness of the drug explained the reason for the refusal. At the sametime, he expressed the following idea:

"I believe that the citizens of Ukraine are people and, sorry for such a comparison, they are not rabbits, we have no right to experiment on them" [18].

This statement is an example of the intention of devaluing the opponent and is quite challenging. We can also distinguish a metaphorical comparison of people with animals (rabbits). The purpose of this statement aims to construct a certain attitude among the citizens of their country concerning Russian products.

Marketing activities and, in particular, the mechanisms for constructing advertising text are vivid examples of the use of the comparison mechanism for manipulative purposes. The comparison mechanism, in this case, has several features, among which are the emphasis on the quantitative component in comparison with other competitors (for example, the price difference), the use of such categories as "first", "the best", interrogative wording of the text (for example, "what can be better than...") and other features of the advertising text [17]. 
For instance, in the advertising text of the "GEL Optima" brand, you can see the use of such verbal characteristics like "as one of the best means", as well as "...it has one significant advantage and difference its price," comparing it with the "Fairy" detergent [15].

This example il lustrates the application of the comparison mechanism, where we can talk about the use of manipulative verbal formulations such as "the best" and "significant advantage". However, in this case, we can not speak about the manipulative depreciation of the competitive brand. Here we are talking mainly about healthy competition.

The comparison mechanism is also used to build national identity. In some cases, the leaders of different countries compare their nations with their opponents. There are al so cases when the image of another country is used to rally and attract the electorate. As an example, we can cite the statement of the former US President D. Trump, where he compares his policy towards Russia with the policies of former US presidents:

"I was much stricter on Russia than Obama, Bush or Clinton. Perhaps tougher than any president. At the same time, I constantly say that establishing relations with Russia is a good thing. I expect that one day we will have a good relationship again" [16].

In this case, we can talk about a comparison with both the opposing country and the current leaders.

\section{Conclusion}

In this article, the comparison mechanism was considered from the point of view of manipulative influence In the theoretical part, some theoretical directions are al so explored, which aim to clarify and analyse the basics and basic mechanisms of the comparison process.

Starting with psychoanalytic theories, we continued to consider the operation of the comparison mechanism in the context of social psychology. Finally, we have presented some socio-psychological phenomena where we can see the manipulative potential of the comparison mechanism

In the practical part, we looked at some of the application areas of the comparison mechanism in a mani pulative way. In particular, in the political sphere, we examined the process of comparison with several manipulative intentions. For example, British Prime Minister Boris Johnson uses the mechanism of comparison with devaluing as well as with clearly aggressive intent to justify his political decisions.

We also saw that the comparison mechanism is also used in the context of domestic policy. In particular, we considered the use of two manipulative intentions, 
where in one case, the comparison was used to maintain its agenda (the example of the President of Georgia). In another case, the manipulative intention of using the comparison mechanism was to justify the correctness of one's political vector and rally one's internal audience (the example of former US President D.Trump).

In the marketing field, we could consider examples of the classical comparison mechanism where expressions such as " the best", "first", " better than..." are used as verbal markers. In this case, we can talk about healthy economic competition and the desire for the superiority of their product.

\section{REFERENCES}

1. Адибекян А., Элибегова А., Армянофобияв Азербайджане/А. Адибекян, А. Элибегова. - Ер.: “Центр обшественных связей и информации" при аппарате президента Армении, 2013. - 332c

2. Адлер А. Наука жить.79 с. [Adler A. Naukal it. 79s.];

3. Безлатный Д., В., Психология в рекламе: искусство манипуляции общественным сознанием, М.: ООО “Ваш полиграфический партнер”, 2011 $236 \mathrm{c}$

4. Зимбардо Ф., Ляйпе М. Социальное влияние-СПб.: Питер, 2001.-448c.: ил.-(Серия "Мастера психологии")

5. Кермберг Отто Ф., Тяжёлые личностные расстройства. Стратегии психотерапии, Перевод с английского М. И. Завалова под редакцией М. Н. Тимофеевой, Москва, Независимая фирма “Класс", 2000

6. Кохут Хайнц, Анализ самости: Систематический подход к лечению нарциссических нарушений личности/Пер. с англ. - М., “Когито Центр”, 2003. 308c. (Современная психотерапия)

7. Лебон Г. Психология народов и масс / Г. Лебон - «Издательство ACT», 1895

8. Г. Лебон. Психология масс, ООО Издательство “Питер", СанктПетербург, 2015

9. Майерс Д., Социальная психология.- 7-е изд.- СПб.: Питер, 2004.- 794c.

10.ЧалдиниР., Психологиявлияния - Спб.: ПитерКом, 1999. - 272с.: (Серия "Мастерапсихологии")

11.Шибутани T. Социальная психология. Сокращённый перевод c английского В. Б. Ольшанского. Издательство “Прогрсс". Москва 1969, 534c

12.Зырянова Н. М. Ранние сиблинговые исследования. Психологические исследования.

13.https://www.bbc.com, Не все, с кем вы не согласны,-фашисты, 15 марта 2017. 
14.https://www.ekhokavkaza.com Сравнение с Зеленским не в пользу Зурабишвили.

15.https://www.dalsnab.ru/ Универсальное, гелеобразное, пенное, моющее средство GEL Optima.

16.https:/hromadske.ua/ru, Трамп назвал свою политику в отношении РФ суровей, чем у всех президентов США, но выступил за улучшение отношений. 12 января, 2019 20:14.

17.https://psyera.ru, Манипуляция в рекламе.

18.https://www.rbc.ru/ Зеленский отказался сравнивать украинцев с кроликами из-за "Спутника V".

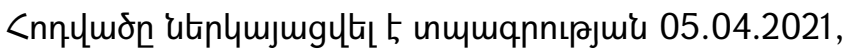

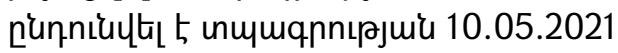

